\title{
CHARACTERISTICS AND FIGURES OF FRESH TILAPIA BACTERIA FROM TAMBAK SAWIYOH SIDOARJO
}

\author{
Sara Wijimulyati ${ }^{1}$, Erfan Andrianto Aritonang', Eka Rista Efrem Burga ${ }^{1}$ \\ ${ }^{1}$ Faculty of Veterinary Medicine, Wijaya Kusuma University, Surabaya, Indonesia \\ Correspondence Author: Sara Wijimulyati \\ E-mail: sara.jnj99@gmail.com
}

\begin{abstract}
This study aims to analyze characteristic and calculate the number of bacterial contamination of fresh nila fish from Sawiyoh pond Sidoarjo, East Java. A total of 30 fresh nila fish were taken and examined at the Microbiology Laboratory Faculty of Medicine Wijaya Kusuma Surabaya University. This research is a descriptive study with observational methods. The step of bacterial enrichment was carried out on BPW (Buffered Pepton Water) media. The bacterial identification procedure uses selective media SSA (SalmonellaShigella Agar), Gram staining, and tests on TSIA media (Triple Sugar Iron Agar). The procedure for calculating the total bacteria using TPC (Total Plate Count) on NA (Nutrient Agar) media. The results on selective SSA media in 30 samples showed suspect Salmonella sp. with the characteristics of colorless colonies with black dots in the middle. The results of Gram staining in 30 samples showed that the bacteria were Gram negative in the form of rods. Test results on TSIA media identified one positive sample of Salmonella sp. (sample 09) with characteristics of the red slope of the media, the base of the media is yellow, and H2S is formed. The results of the calculation of total bacteria by the TPC method showed that the total bacterial total was $15.8 \times 105 \mathrm{CFU} /$ gram. The limit of microbial contamination according to the 2009 SNI for fresh fish is $5 \times 105 \mathrm{CFU} /$ gram so that fresh nila fish from Sawiyoh Sidoarjo pond has a number of bacterial contamination above the stipulated threshold.
\end{abstract}

Keywords: Nila Fish, Gram Staining, Salmonella sp., Salmonella-Shigella Agar, Total Plate Count, Triple Sugar Iron Agar

\section{ABSTRAK}

Penelitian ini bertujuan untuk menganilsa karakeristik dan menghitung angka cemaran bakteri pada ikan nila segar yang berasal dari tambak Sawiyoh Kabupaten Sidoarjo, Jawa Timur. Sebanyak 30 ekor ikan nila segar diambil dan diperiksa di Laboratorium Mikrobiologi Fakultas Kedokteran Universitas Wijaya Kusuma Surabaya. Penelitian ini merupakan penelitian deskriptif dengan metode observasional. Tahap pengayaan bakteri dilakukan pada media BPW (Buffered Pepton Water). Prosedur identifikasi bakteri menggunakan media selektif SSA (Salmonella-Shigella Agar), pewarnaan Gram, dan uji pada media TSIA (Triple Sugar Iron Agar). Prosedur penghitungan total bakteri menggunakan TPC (Total Plate Count) pada media NA (Nutrient Agar). Hasil pada media selektif SSA pada 30 sampel menunjukkan adanya suspect bakteri Salmonella sp. dengan ciriciri koloni tidak berwarna dengan titik hitam di tengahnya. Hasil pewarnaan Gram pada 30 sampel menunjukkan bahwa bakteri bersifat Gram negatif berbentuk batang. Hasil uji pada media TSIA teridentifikasi satu sampel positif bakteri Salmonella sp. (sampel 09) dengan ciri-ciri bagian lereng media berwarna merah, bagian dasar media berwarna kuning, dan terbentuk $\mathrm{H}_{2} \mathrm{~S}$. Hasil perhitungan total bakteri dengan metode TPC menunjukkan hasil rata-rata total bakteri sebesar 15,8 $\times 10^{5}$ CFU/gram. Batas cemaran mikroba menurut SNI tahun 2009 pada ikan segar adalah $5 \times 10^{5}$ CFU/gram sehingga, ikan nila segar dari tambak Sawiyoh Sidoarjo memiliki angka cemaran bakteri di atas ambang batas ketentuan.

Kata kunci: Ikan Nila, Pewarnaan Gram, Salmonella sp., Salmonella-Shigella Agar, Total Plate Count, Triple Sugar Iron Agar

\section{INTRODUCTION}

Food or food is a substance that people consume every day as a source of nutrients and energy to meet the needs for the maintenance, growth, and replacement of damaged body cells. Some nutrients that the body needs to support it include carbohydrates, proteins, fats, vitamins, minerals, and water (Ciptanto, 2010). Fish meat is a source of animal nutrition that is widely selected by Indonesian people. Fish nutritional value is better than other animal meat. This is because fish meat has an gastrointestinal value as well as higher biological value. In general the 
composition of fish meat consists of 15$24 \%$ protein, $1-3 \%$ glycogen/carbohydrate, $1-22 \%$ fat, $66-84 \%$ water, and other organic matter of $0.8-2 \%$. One of the fish meat consumed by the community is tilapia meat (Arifah, 2010).

Tilapia meat has a thick texture and soft, it makes tilapia as one of the freshwater fish that is often consumed by Indonesian people. Tilapia were first brought to Indonesia in 1969. The ability of tilapia to adapt very well to the environment and the procedure of tilapia spawning is quite easy to make the business of tilapia aquaculture become one of the commodity food sources of aquaculture growing Indonesia (Nugroho, 2013).

Aquaculture food sources are susceptible to contaminated pathogenic microorganisms, such as bacteria. Bacterial contamination in fish occurs due to aquaculture conditions, processing, and the distribution of fish from cultivation locations to unhygienic marketing. Imperfect or less precise processing of fish polluted bacteria can be a disease for those who consume it (Tapotubun et al, 2008). One of the pathogenic bacteria that become a threat of contamination in aquaculture products is Salmonella $\mathrm{sp}$ bacteria. Salmonella SP bacteria are often found in the waters of a less healthy cultivation location. The hot and humid environment in tropical countries such as Indonesia stimulated Salmonella sp. has been contaminating food sources will easily do breeding (Akbar et al, 2016).

Salmonella sp. Bacteria can cause a disease called Salmonellosis. The case of Salmonellosis is widely reported in tropical countries, but the reported case percentage is still relatively small compared to the actual occurrence (Budiarso dan Bello, 2009). Salmonellosis often causes gastroenteritis in humans, some of the symptoms arising from Salmonellosis, such as fever, abdominal pain, diarrhea, and vomiting. (Ihsan et al, 2018). Therefore, the Food and Drug
Control Agency (2009) states that fish food and fishery products should not contain the contamination of Salmonella sp.

Based on the background it is important analyze the characteristic and calculate the number of bacterial contamination in fresh tilapia derived from the pond Sawiyoh Sidoarjo Regency which is one site of fish farming Indigo is distributed to the markets in Sidoarjo and Surabaya area. In this research analysis characteristics of bacteria directed to Salmonella SP while counting the number of bacterial contamination done in general. The final part of the article will be elaborated several methods of storing and processing simple fresh fish which aims to remove bacterial contamination in fresh fish. The results of this research can be information for the community and the description of the storage and processing of fresh fish is good and true becomes a necessity.

\section{METHODS}

This research is a descriptive study with observational methods. The research was held from 10 to 13 July 2018. This research-free variable is Salmonella sp. bacteria, the variable is the medium of SSA (Salmonella-Shigella Agar), Gram staining, TSIA media (Triple Sugar Iron Agar), and the media NA (Nutrient Agar).

\section{Research materials}

The materials used in this research are media so that NA (Nutrient agar), Media bpw (buffered Pepton Water), Selective media SSA (salmonella-shigela agar), Media tsia (Triple Sugar Iron agar), physiological $\mathrm{NaCl}$, dye fibreboard violet $1 \%$, Lugol iodine, Safranin, alcohol 70\%, alcohol 95\%, spirtus, aquadest, and oil emersi.

The tools used in this research are cool boxes, digital scales, incubators, knives, reaction tubes, test tube shelves, glass stirrers, beaker cups, measuring cups, petri bowls, sterile plastics, labels, mortar, 
stemper, autoclave, Stomacher, Binocular Microscope, Object glass, cover glass, colony counter, Bunsen burner, bent stem, ose, needle, pipette, tweezers, pipette, spot staining, wood clamp, lighter, tissue, and suction paper.

\section{Sampling}

Sampling were done in Tilapia pond Sawiyoh Sidoarjo, East Java. The samples collected were fresh tilapia as many as 30 tails $10-15 \mathrm{~cm}$. Sample tilapia are inserted in sterile plastic, labeled then inserted into the cool box containing ice. Samples collected by the analysis of characteristics and calculation of bacterial contamination in the laboratory of Microbiology of the Faculty of Medicine Universitas Wijaya Kusuma Surabaya.

\section{Research procedure Enrichment phase}

The enrichment media used in this research is BPW (Buffered Pepton Water) which is a commonly used medium for homogenization and reproduction of Salmonella sp. Samples of fresh fish were taken from the abdominal meat including the scales, but Excluding the gastrointestinal tract is then weighed as much as 25 grams. Samples were crushed with mortar and stemper then inserted into the $225 \mathrm{ml}$ of BPW media. After it was homogenized into the stomacher for two minutes, then incubated at $37{ }^{\circ} \mathrm{c}$ for 24 hours (Insani, 2017).

\section{Bacterial characteristics Analysis}

The analysis of bacterial characteristics was conducted using SSAselective media (Salmonella-Shigella Agar), Gram staining, and TSIA (Triple Sugar Iron Agar) media. The analysis of bacterial characteristics using SSAselective media is done by the streak method directly from the add-on media to the SSA media, then incubated at $37^{\circ} \mathrm{c}$ for 24 hours. The positive result of the Baktri of Salmonella sp. will show the unenamelled colony with black dots in the middle (Yuswananda, 2015).

The subsequent analysis of bacterial characteristics is by Gram staining. Bacterial preparations of the SSA-selective medium are applied to the glass object, then the fixated using Bunsen fire. Preparations are colored with a solution of a $1 \%$ violet fibres and are allowed for one minute, and then the preparations are washed with flowing water and then dried. After drying, the preparations are treated with an iodine lugol solution and let sit for one minute, and then the preparations are washed with flowing water and dried anginkan. After drying, the preparation is $95 \%$ alcohol for 30 seconds, then it is washed with flowing water and then dried anginkan. After drying, the preparation is taken in the dye solution safranin and is allowed for one minute, then washed with flowing water and dried with suction paper (Kartika et al, 2014). After drying, the preparations are examined under a microscope with an magnification of 1000x (Insani, 2017).

The confirmation test of bacterial characteristics in this study was conducted by testing on TSIA media. Identification is done by taking the colony on the SSA media, then inoculated with the needle into TSIA media. The method inoculation by way of streak on the parts of the mirror and stabbed at the base. Media was incubated at $37^{\circ} \mathrm{c}$ for 24 hours. Interpretation of the positive results of the existence of Salmonella sp. is a slope of red TSIA media and a base of yellow TSIA media (SNI, 2008). If positive gas will be formed oxygen gas $(\mathrm{O} 2)$ while, if the positive hydrogen sulfide (H2S) will be formed black deposits on the media TSIA.

\section{Bacterial contamination Number Calculation}

The method used to calculate the bacterial contamination number is TPC (Total Plate Count). The procedure is to include a $1 \mathrm{ml}$ sample of the enrichment 
medium in the reaction tube 1 and then added with $9 \mathrm{ml}$ of physiological $\mathrm{NaCl}$ to produce a 10-1 dilution, this is done until the dilution of 10-4. The dilution results of 10-3 and 10-4 were taken $1 \mathrm{ml}$ and moved into the petri dish containing the media NA (Nutrient Agar), then spread with a sterile bent stem and incubated at $37{ }^{\circ} \mathrm{c}$ for 24 hours in reverse position. The calculated samples are samples with a colony amounting to 25-250 (SNI, 2008).

\section{Sample Data Analysis}

Analysis of bacteria characteristics are using descriptive analysis through SSA-selective media, Gram staining, and TSIA media. Calculation of bacterial contamination using TPC.

\section{RESULTS}

\section{Enrichment phase}

The results of observations on the media BPW (Buffered Pepton Water) After 24 hours is encountered turbidity and a distinctive smell that is a sign of bacterial growth (Yuswananda, 2015).

\section{Bacterial Characteristics Analysis Results}

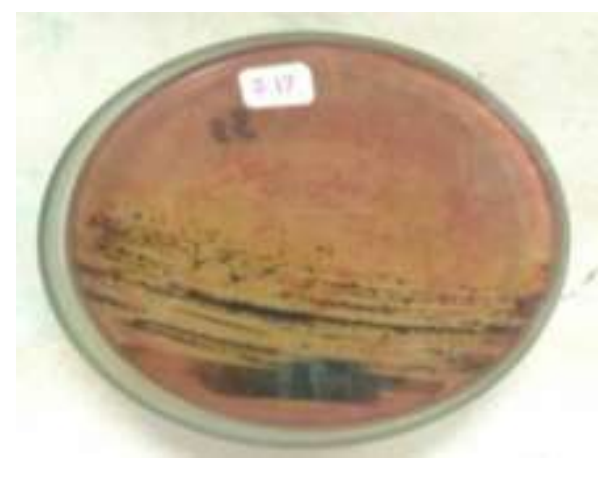

Figure 1. The depiction of suspect bacteria Salmonella sp. in SSA Media Test results of 30 fresh tilapia
samples on SSA-selective media
(Salmonella-Shigella Agar) show the presence of colorless colonies with black dots in the middle. This indicates that the bacteria produce hydrogen sulfide (H2S), indicating that the result of the isolation of bacteria is a suspect of Salmonella sp.Test result from 30 samples of fresh tilapia on Gram staining showed all samples had a reddish pink and stem-shaped bacterial image, indicating Gram-negative bacteria.

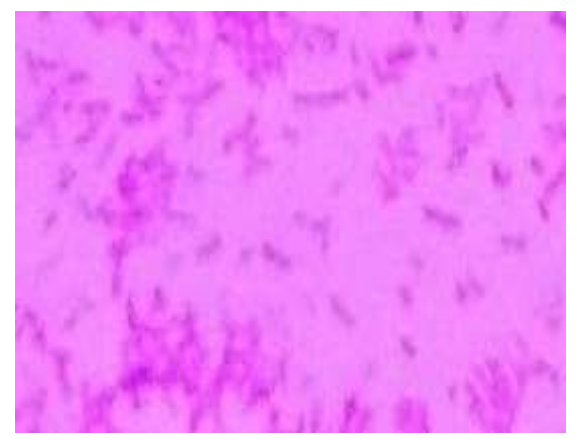

Figure 2. Microscopic bacteria overview of Gram staining with 1000x magnification

Test results 30 Fresh tilapia samples on SSA-selective media and Gram staining that showed the presence of suspect of Salmonella sp. bacteria followed by a test of TSIA (Triple Sugar Iron Agar). Test results in TSIA Media show one sample (sample 09) Positive tainted Salmonella sp bacteria. This is confirmed in the media results of TSIA which shows the slope of the media in red and the base of the media is yellow,

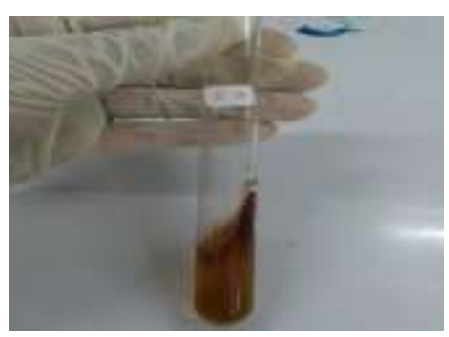

Figure 3. Positive representation of TSIA Media test results 
Table 1. Characteristics of bacteria on Gram staining and test of TSIA Media Fresh Tilapia sample from the pond Sawiyoh Sidoarjo

\begin{tabular}{|c|c|c|c|}
\hline \multirow{2}{*}{$\begin{array}{c}\text { No. } \\
\text { Sample }\end{array}$} & \multicolumn{2}{|c|}{$\begin{array}{c}\text { Bacterial depictions of Gram } \\
\text { staining }\end{array}$} & \multirow{2}{*}{$\begin{array}{l}\text { Overview of } \\
\text { the colony on } \\
\text { TSIA Media }\end{array}$} \\
\hline & Colour & Bentuk & \\
\hline 01 & Pink redness & Stem & $\mathrm{K} / \mathrm{K}$ \\
\hline 02 & Pink redness & Stem & $\mathrm{K} / \mathrm{K}$ \\
\hline 03 & Pink redness & Stem & $\mathrm{K} / \mathrm{K}$ \\
\hline 04 & Pink redness & Stem & $\mathrm{K} / \mathrm{K}$ \\
\hline 05 & Pink redness & Stem & $\mathrm{K} / \mathrm{K}$ \\
\hline 06 & Pink redness & Stem & $\mathrm{K} / \mathrm{K}$ \\
\hline 07 & Pink redness & Stem & $\mathrm{M} / \mathrm{M}$ \\
\hline 08 & Pink redness & Stem & $\mathrm{K} / \mathrm{K}$ \\
\hline 09 & Pink redness & Stem & $\mathrm{M} / \mathrm{K}$ \\
\hline 10 & Pink redness & Stem & $\mathrm{K} / \mathrm{K}$ \\
\hline 11 & Pink redness & Stem & $\mathrm{K} / \mathrm{K}$ \\
\hline 12 & Pink redness & Stem & $\mathrm{K} / \mathrm{K}$ \\
\hline 13 & Pink redness & Stem & $\mathrm{M} / \mathrm{M}$ \\
\hline 14 & Pink redness & Stem & $\mathrm{K} / \mathrm{K}$ \\
\hline 15 & Pink redness & Stem & $\mathrm{K} / \mathrm{K}$ \\
\hline 16 & Pink redness & Stem & $\mathrm{K} / \mathrm{K}$ \\
\hline 17 & Pink redness & Stem & $\mathrm{K} / \mathrm{K}$ \\
\hline 18 & Pink redness & Stem & $\mathrm{K} / \mathrm{K}$ \\
\hline 19 & Pink redness & Stem & $\mathrm{K} / \mathrm{K}$ \\
\hline 20 & Pink redness & Stem & $\mathrm{K} / \mathrm{K}$ \\
\hline 21 & Pink redness & Stem & $\mathrm{K} / \mathrm{K}$ \\
\hline 22 & Pink redness & Stem & $\mathrm{M} / \mathrm{M}$ \\
\hline 23 & Pink redness & Stem & $\mathrm{K} / \mathrm{K}$ \\
\hline 24 & Pink redness & Stem & $\mathrm{K} / \mathrm{K}$ \\
\hline 25 & Pink redness & Stem & $\mathrm{K} / \mathrm{K}$ \\
\hline 26 & Pink redness & Stem & $\mathrm{K} / \mathrm{K}$ \\
\hline 27 & Pink redness & Stem & $\mathrm{K} / \mathrm{K}$ \\
\hline 28 & Pink redness & Stem & $\mathrm{K} / \mathrm{K}$ \\
\hline 29 & Pink redness & Stem & $\mathrm{M} / \mathrm{M}$ \\
\hline 30 & Pink redness & Stem & $\mathrm{K} / \mathrm{K}$ \\
\hline
\end{tabular}

Description:

$\mathrm{K} / \mathrm{K}$ : The yellow slope, yellow base

$\mathrm{M} / \mathrm{K}$ : Red slope, yellow base

M/M: Red slope, Red Bottom

\section{Calculation of bacterial contamination}

Table 2. Result counting bacteria contamination per 25 grams fresh tilapia samples from the Tambak Sawiyoh Sidoarjo

\begin{tabular}{cccc}
\hline $\begin{array}{c}\text { No. } \\
\text { Sample }\end{array}$ & $\begin{array}{c}\text { Total Bacteria } \\
(\text { CFU/gram) }\end{array}$ & $\begin{array}{c}\text { No. } \\
\text { Sample }\end{array}$ & $\begin{array}{c}\text { Total Bacteria } \\
\text { (CFU/gram) }\end{array}$ \\
\hline 01 & $3,6 \times 10^{5}$ & 16 & $15,1 \times 10^{5}$ \\
02 & $11,3 \times 10^{5}$ & 17 & $21,6 \times 10^{5}$ \\
03 & $18,6 \times 10^{5}$ & 18 & $3,0 \times 10^{5}$
\end{tabular}




\begin{tabular}{cccc}
\hline $\begin{array}{c}\text { No. } \\
\text { Sample }\end{array}$ & $\begin{array}{c}\text { Total Bacteria } \\
\text { (CFU/gram) }\end{array}$ & $\begin{array}{c}\text { No. } \\
\text { Sample }\end{array}$ & $\begin{array}{c}\text { Total Bacteria } \\
\text { (CFU/gram) }\end{array}$ \\
\hline 04 & $5,7 \times 10^{5}$ & 19 & $17,0 \times 10^{5}$ \\
05 & $2,4 \times 10^{5}$ & 20 & $4,4 \times 10^{5}$ \\
06 & $13,2 \times 10^{5}$ & 21 & $8,9 \times 10^{5}$ \\
07 & $22,2 \times 10^{5}$ & 22 & $4,7 \times 10^{5}$ \\
08 & $25,0 \times 10^{5}$ & 23 & $5,6 \times 10^{5}$ \\
09 & $11,1 \times 10^{5}$ & 24 & $1,7 \times 10^{5}$ \\
10 & $10,1 \times 10^{5}$ & 25 & $24,4 \times 10^{5}$ \\
11 & $23,3 \times 10^{5}$ & 26 & $4,4 \times 10^{5}$ \\
12 & $20,8 \times 10^{5}$ & 27 & $2,8 \times 10^{5}$ \\
13 & $4,4 \times 10^{5}$ & 28 & $5,0 \times 10^{5}$ \\
14 & $3,7 \times 10^{5}$ & 29 & $11,3 \times 10^{5}$ \\
15 & $21,4 \times 10^{5}$ & 30 & $5,5 \times 10^{5}$ \\
\hline Rata-Rata Cemaran Bakteri Sampel & \multicolumn{2}{c}{ Batas Maksimum Cemaran Bakeri } \\
\multicolumn{2}{r}{} \\
\hline
\end{tabular}

\section{DISCUSSION}

\section{Enrichment phase}

The material used for the multiplication of bacteria is the media BPW (Buffered Peptone Water). BPW Media is a bacterial enrichment medium designed to help the recovery of the badly damaged Salmonella sp. bacteria before being transferred to selective media. BPW Media contain peptone proteosa which is a source of carbon, nitrogen, vitamins, and minerals. The existing sodium chloride will maintain the osmotic balance and become a phosphate buffer medium. Media BPW produces high levels of resuscitation for injured bacteria and supports intense growth (Insani, 2017).

\section{Bacterial characteristics Analysis}

Inoculation in SSA media (Salmonella-Shigella Agar) is done after the enrichment phase by using BPW media. SSA Media is one of the selective medium used for isolation and identification of Salmonella sp. bacteria (Yuswananda, 2015). SSA Media contains bile salts, brilliant green, and sodium citrate which serves to inhibit the growth of Gram-positive bacteria and some bacteria that can ferment lactose (Tille, 2014).

Based on the test results of 30 samples of fresh tilapia in the SSAselective medium, the 30 samples were formed in colorless colonies with black dots in the center (Fig. 1). The colony's depiction of colorless with a black dot in the middle is due to the Salmonella sp. bacteria can produce hydrogen sulfide (H2S). Sodium citrate contained in SSA media reacts with hydrogen sulfide (H2S) thus causing black deposits at the center of the colony (Yuswananda, 2015). Based on these results then allegedly 30 samples of fresh tilapia from the pond Sawiyoh Sidoarjo contaminated Salmonella sp. To confirm this then carried out a follow-up test, namely Gram staining and test on TSIA media.

Gram staining done in this research is to use $1 \%$ violet fibreboard solution, Lugol iodine, alcohol 95\%, and Safranin. The usefulness of Gram staining is to know the nature and morphology of the bacteria. Salmonella sp. is a Gramnegative and stem-shaped bacteria, Gramnegative staining will result in reddish pink color. This is because the cell wall of thin bacteria and the outer casing of bacteria will fade from alcohol use (Putri, 2016). 
Red color on the coloration of Safranin will be tied by bacteria so that, the color that existed is reddish pink (Neja, 2014) whereas, in Gram-positive bacteria will produce a purple color resulting from bacteria that retain the complex of crystal colour substances Violet (Fitri dan Yasmin, 2011).

The color difference in Grampositive bacteria with Gram-negative bacteria indicates that there are differences in the structure of the cell walls between the two bacteria. Gram-positive bacteria have a cell wall structure with a thick peptidoglykan content whereas, negative Gram bacteria have a cell wall structure with a thin Peptidoglykan content (Fitri dan Yasmin, 2011).

Based on the Gram staining test carried out on 30 samples, the 30 samples had bacteria with a reddish-pink picture seen in a microscope with $1000 \mathrm{x}$ magnification (Fig. 2). Bacterial depictions of microscopic observation identifying the growing bacteria are Gram-negative and have rod-shaped morphology. In accordance with the research conducted by (Putri, 2016) that the stem-shaped bacteria and Gram-negative ones derived from SSA media are allegedly a colony of Salmonella sp bacteria. Therefore to confirm it is conducted test The test of TSIA Media.

TSIA test is a complete test that can demonstrate the formation of hydrogen sulfide (H2S), the formation of oxygen gas $(\mathrm{O} 2)$, as well as indicate the inability of bacteria in the fermentation of lactose and sucrose (Budiarso dan Bello, 2009). TSIA Media contains lactose and sucsuse in concentrations of $1 \%$, glucose $1 \%$, and phenol red. The content that causes the change of media color from red-orange to yellow in an acidic atmosphere. The basic part of TSIA media is to ferment glucose while the slope will ferment lactose and suclise (Saraswati, 2012). When Salmonella sp. grows in TSIA media it will be a discoloration of red skewed parts; The base is yellow; Positive hydrogen sulfide
(H2S) black color; And gases that can be formed or not (SNI, 2008).

Positive Salmonella sp. in TSIA media will show the skewed portion of the media remains red, meaning Salmonella sp. is an alkaline and does not ferment lactose and sucsuse whereas, the color of the base of the media will change color to yellow which indicated, Salmonella sp. fermentation of glucose. Positive gas formation is seen from the rupture of media or the promotion of media. This occurs because of the results of the fermentation of $\mathrm{H} 2$ and $\mathrm{CO} 2$ whereas, the formation of a positive hydrogen sulfide $(\mathrm{H} 2 \mathrm{~S})$ is characterized by a black deposition. It is in accordance with the statement ICMSF (1996) that the Salmonella sp. bacteria are able to produce acids and produce gases from glucose. Most of the isolates of Salmonella sp. from clinical specimens form a varied hydrogen sulfide (H2S) (Radji, 2009). Other content in TSIA media is sodium trisulphate which is a substrate of hydrogen sulfide (H2S) and ferro sulfate which will produce $\mathrm{FeS}$ (Arifah, 2010). According to ((Budiarso dan Bello, 2009) The cause of the emergence of black is the reaction of hydrogen sulfide (H2S) with FeS thus producing ferrous sulfide.

Based on the explanation above, then the researcher identified one sample out of 30 samples of fresh tilapia from the pond Sawiyoh Sidoarjo tested using TSIA media that shows a positive sample of contaminated Salmonella sp. (sample 09) whereas, 29 samples Other negative bacterial contamination of Salmonella sp. One positive sample of contaminated Salmonella sp. In confirmation based on the test results on the TSIA media is on the slope of the media in red and on the base of the media is yellow and There is hydrogen sulfide (H2S).

\section{Bacterial contamination Number Calculation}

The procedure of counting bacterial contamination using the TPC (Total Plate 
Count) method in the media NA (Nutrient Agar), is because the media NA is a nutrient rich media (Panagan, 2011). Based on the results of Penghitngan done in 30 samples of fresh tilapia from the pond Sawiyoh Sidoarjo, there are 17 samples that have a total colony between 17-250 and 13 samples that have a total colony above 250. A total of 13 samples that had a number of colonies above 250 could not be calculated the number of bacteria. This is in accordance with the calculation instructions TPC (SNI, 2008), i.e. the sample is calculated is a sample that has a colony amounted to 25-250.

Based on calculated results of the average known bacterial contamination in fresh tilapia samples from the pond Sawiyoh Sidoarjo were obtained that the tilapia has a number of bacterial contamination that exceeds the threshold of bacterial contamination required by Indonesian national standard (SNI) year 2009. It is likely due to a water source contaminated by the surrounding environment. The location around the pond of Sawiyoh Sidoarjo are containing garbage coming from the inhabitants around the pond. The dirty water will lead to increased bacterial contamination that will impact the increase in the TPC content of the aquaculture fish (Susianawati, 2006).

Based on the security review of Indonesian National Standard (SNI) in 2009, said that TPC is not generally related to the dangers of food safety, but beneficial in terms of quality determination, shelf life or half-life, contamination conditions, and Hygiene status of food production process.

According to Damongilala (2009) The increase of microbial contamination in fish is also suspected because of extrinsic factors that support bacterial growth, including environmental conditions and fish product handling. Nevertheless there are some normal bacteria in fish, but the bacteria will interfere with the metabolic process of fish when handled unproperly (Wulandari, 2016). Some types of normal bacteria contained in the body of fish, are bacteria Pseudomonas sp., Serratia sp., Achromobacter sp., Flavobacterium sp., Micrococcus sp., Vibrio sp., and Bacillus sp. whereas, Salmonella sp. and Staphylococcus sp. no should be present in fresh fish, unless the fish is captured from water contaminated with Salmonella sp. or Staphylococcus sp. or due to contamination during product handling and processing (De Fretes et al, 2015).

Based on these findings, it is important for people to properly store and process fresh fish. Good and proper storage and processing can eliminate bacterial contamination in fresh fish. Below is a review of simple methods of storing and processing fresh fish that people can easily apply.

Storage of fresh fish can be done in low temperatures (under $5{ }^{\circ} \mathrm{c}$ ). A low temperaturesr will result in the intracellular alteration of the bacteria so that the bacteria will lose the power of life. Next is the way of scanning, scanning is one of the methods that can be done to extend the save power of fish. This principle of scanning is to soak fresh fish in salt solution and then proceed with boiling. According to research (Alyani et al, 2016) The centration of salt solution $10 \%$ and boiling for 20 minutes is the most optimal method of scanning of fish nutrients. Fish results can be cooked in accordance with the wishes of consumers.

The perfect processing or cooking of fresh fish or other fisheries purchased in traditional markets, fish markets, or other fish sales locations is important as an advanced effort to eliminate the adverse effects of contamination of bacteria. Fish processing also aims to enrich the taste of fish so that it will increase the palatability. Some methods of processing or cooking can be done, such as frying, boiling, or seaming. The main principle of good cooking is to heat the fish until all parts of the fish are cooked to release steam. In general, bacterial contamination in fresh fish will die at high temperatures during 
cooking process, as an example of Salmonella sp. bacteria will die at $56^{\circ} \mathrm{c}$ and in dry state (BPOM, 2015).

The recommendation of fresh fish fry is at $180{ }^{\circ} \mathrm{c}$ for 3-4 minutes, high temperature and long-frying will affect food quality and safety. It is best to fry the fish using cooking oil that is good quality with a volume comparison of cooking oil and foodstuffs amounting to 6:1 (BPOM, 2015).

Another thing in addition to storage methods and fish processing is to keep the hygiene of the tools which used during the storage process until the presentation. Washing equipment used before and after use in storage, processing, and serving fish should be noted to ensure the safety of food products until ready to be consumed. Purification of these tools is good to do using hot soap water and rinsed with flowing water.

\section{CONCLUSION}

SSA-Selective media test results (Salmonella-Shigella Agar), on 30 samples of fresh tilapia from the pond Sawiyoh Sidoarjo showed a colorless colony with black dots in the middle. Gram dyeing results, showing 30 samples of fresh tilapia from the pond Sawiyoh Sidoarjo showed the description of bacteria is Gram negative with stem formation. The results of the test with the media TSIA (Triple Sugar Iron Agar) in 30 samples fresh tilapia from the pond Sawiyoh Sidoarjo, showed a positive sample of contaminated Salmonella sp.

The result of counting bacteria contamination using the TPC (Total Plate Count) method shows the average result of the contamination of fresh tilapia bacteria from the Sawijn Sidoarjo pond containing bacterial contamination above the required threshold of SNI 2009.

\section{REFERENCE}

Akbar, Y. M., Diansyah, G., dan Isnaini.
2016. Deteksi Cemaran Bakteri Salmonella sp. pada Ikan Teri (Stolephorus spp.) Hasil Perikanan di Perairan Sungsang Kabupaten Banyuasin Sumatera Selatan. Maspari Journal. 8(1) pp: 25-30.

Alyani, F., Ma'ruf, W. F., Anggo, A. D., 2016. Pengaruh Lama Perebusan Ikan Bandeng (Chanos chanos Forsk) Pindang Goreng Terhadap Kandungan Lisin dan Protein Terlarut. Jurnal Pengolahan dan Bioteknologi Hasil Perikanan. 5(1) pp: 88-93.

Arifah, I. N. 2010 Analisis Mikrobiologi pada Makanan. Universitas Sebelas Maret.

Badan Pengawas Obat dan Makanan. 2009. Penetapan Batas Maksimum Cemaran Mikroba dan Kimia dalam Makanan. Jakarta Indonesia.

Badan Pengawas Obat dan Makanan. 2015. Pedoman Cara Menggoreng Pangan yang Baik untuk Usaha Mikro, Kecil, dan Menengah (UMKM). Jakarta Indonesia.

Budiarso, T. Y. dan Bello, M. J. X. 2009. Deteksi Cemaran Salmonella pada Daging Ayam yang dijual di Pasar Tradisional di Wilayah Kota Yogyakarta. Yogyakarta.

Ciptanto, S. 2010. Top 10 Ikan Air Tawar Panduan Lengkap Pembesaran Secara Organik di Kolam Air, Kolam Terpal, Karamba, dan Jala Apung. Yogyakarta: Lili Publisher.

Damongilala, L. J. 2009. Kadar Air dan Total Bakteri pada Ikan Roa (Hemirhampus sp.) Asap dengan Metode Pencucian Bahan Baku Berbeda. Jurnal Ilmiah Sains. 9(2) pp: 190-198.

Fitri, L. dan Yasmin, Y. 2011. Isolasi dan Pengamatan Morfologi Koloni Bakteri Kitinolitik. Jurnal Ilmiah Pendidikan Biologi. 3(2) pp: 2025.

De Fretes, M., Gunaedi, T., dan Surbakti, S. B. R. 2015. Bakteri Proteolitik Padalkan Tongkol 
(Euthynusaffinis) Hasil Proses Pengasapan Tradisional dan Modern. Jurnal Biologi Papua. 7(1) pp: 1-8. [doi: https://doi.org/10.31957/jbp.425].

ICMSF. 1996. Microorganism in Foods. Microbiological Spesification of Food Pathogens. London.

Ihsan, B., Abdiani, I., M., dan Isnaini. 2018. Deteksi dan Identifikasi Bakteri Salmonella sp. pada Ikan Bandeng yang Dijual di Pasar Gusher Kota Tarakan. Jurnal Harpodon Borneo. 11(1) pp: 4651.

Insani, D. A. 2017. Isolasi dan Identifikasi Bakteri Salmonella sp. pada Ikan Bandeng (Chanoschanos) dengan Uji Biokimia. Universitas Wijaya Kusuma Surabaya.

Kartika, E., Khotimah, S., dan Yanti, A. H. 2014. Deteksi Bakteri Indikator Keamanan Pangan pada Sosis Daging Ayam di Pasar Flamboyan Pontianak. Protobiont. 3(2) pp: 111-119.

Neja, S. A. 2014. Veterinary Microbiology Laboratory Manual. Nekemte: Wollega University.

Nugroho, E. 2013 Nila Unggul\#1. Jakarta: Penebar Swadaya.

Panagan, A. T. 2011. Isolasi Mikroba Penghasil Antibiotika dari Tanah Kampus Unsri Indralaya Menggunakan Media Ekstrak Tanah. Jurnal Penelitian Sains. 14(3) pp: 37-40.

Putri, R. W. A. 2016. Identifikasi Bakteri E. coli dan Salmonella sp. Pada Jajanan Batagor di Sekolah Dasar Negeri di Kelurahan Pisangan, Cirendeu, dan Cempaka Putih Kecamatan Ciputat Timur. Universitas Islam Negeri Syarif
Hidayatullah.

Radji, M. 2009. Buku Ajar Mikrobiologi Panduan Mahasiswa Farmasi dan Kedokteran. Jakarta: Penerbit ECG. Saraswati, P. 2012 Uji Bakteri Salmonella sp. pada Telur Bebek, Telur Puyuh, dan Telur Ayam Kampung yang Diperdagangkan di Pasar Liluwo Kota Gorontalo. Universitas Negeri Gorontalo.

Standar Nasional Indonesia. 2008. Metode Pengujian Cemaran Mikroba Dalam Daging, Telur dan Susu, Serta Hasil Olahannya.

Susianawati, R. 2006. Kajian Penerapan GMP dan SSOP pada Produk Ikan Asing Kering dalam Upaya Peningkatan Keamanan Pangan di Kabupaten Kendal. Universitas Diponegoro.

Tapotubun, A. M., Nanlohy, E. E. E. M., dan Louhenapessy, J. M. 2008. Efek Waktu Pemanasan Terhadap Mutu Presto Beberapa Jenis Ikan. Ichthyos. 7(2) pp: 65-70.

Tille, P. 2014. Baily and Scott's Diagnostic Microbiology. USA: Elsevier.

Wulandari, N. K. M. 2016. Uji Angka Lempeng Total dan Identifikasi Escherichia coli Dalam Jamu Gendong Beras Kencur Yang Dijual Di Pasar Sambilegi Wilayah Maguwoharjo Kecamatan Depok Kabupaten Sleman Yogyakarta. Universitas Sanata Dharma Yogyakarta.

Yuswananda, N. P. 2015 Identifikasi Bakteri Salmonella sp. pada Makanan Jajanan di Masjid Fathullah Ciputat Tahun 2015. Universitas Islam Negeri Syarif Hidayatullah Jakarta. 